\title{
LEGISLACIÓN DE DERECHO ADMINISTRATIVO
}

\author{
Fernando GonZÁlez BotijA \\ Departamento de Derecho Administrativo \\ Facultad de Derecho de la UCM \\ dp143@ucm.es
}

- Real Decreto-ley 7/2016, de 23 de diciembre, por el que se regula el mecanismo de financiación del coste del bono social y otras medidas de protección al consumidor vulnerable de energía eléctrica (Boletín Oficial del Estado, núm. 310, 24 de diciembre de 2016).

- Real Decreto 637/2016, de 9 de diciembre, por el que se prorroga el Plan Estatal de Fomento del Alquiler de Viviendas, la Rehabilitación Edificatoria y la Regeneración y Renovación Urbanas 2013-2016, regulado por el Real Decreto 233/2013, de 5 de abril (Boletín Oficial del Estado, núm. 298, 10 de diciembre de 2016).

- Real Decreto-ley 5/2016, de 9 de diciembre, de medidas urgentes para la ampliación del calendario de implantación de la Ley Orgánica 8/2013, de 9 de diciembre, para la mejora de la calidad educativa (Boletín Oficial del Estado, núm. 298, 10 de diciembre de 2016).

- Real Decreto 542/2016, de 25 de noviembre, sobre normas de sanidad y protección animal durante el transporte (Boletín Oficial del Estado, núm. 297, 9 de diciembre de 2016).

- Ley Orgánica 1/2016, de 31 de octubre, de reforma de la Ley Orgánica 2/2012, de 27 de abril, de Estabilidad Presupuestaria y Sostenibilidad Financiera (Boletín Oficial del Estado, núm. 264, 1 de noviembre de 2016).

- Real Decreto 389/2016, de 22 de octubre, por el que se aprueba el Plan Director de la Red de Parques Nacionales (Boletín Oficial del Estado, núm. 257, 24 de octubre de 2016).

- Real Decreto 330/2016, de 9 de septiembre, relativo a medidas para reducir el coste del despliegue de las redes de comunicaciones electrónicas de alta velocidad (Boletín Oficial del Estado, núm. 223, 15 de septiembre de 2016). 
- Real Decreto 294/2016, de 15 de julio, por el que se establece el procedimiento para la gestión de los derechos mineros y de los derechos del dominio público de hidrocarburos afectados por el cambio del sistema geodésico de referencia (Boletín Oficial del Estado, núm. 178, 25 de julio de 2016). 